УДК 340.11/.12:[141.319.8:316]

\title{
ДЕЯКІ ЕВРИСТИЧНІ МОЖЛИВОСТІ АНТРОПОЛОГО-БІОЛОГІЗАТОРСЬКОГО ПІДХОДУ У ЗАГАЛЬНІЙ ТЕОРІї ТА ФІЛОСОФІЇ ДЕРЖАВИ І ПРАВА
}

\author{
Д. Гудима, К. Литвинюк \\ Львівський національний університет імені Івана Франка, \\ вул. Університетська, 1, Львів, Україна, 79000, \\ e-mail:dmytro.hudyma@gmail.com,lutvunykk@gmail.com
}

У статті викладено ідеї щодо можливості розширення методологічного інструментарію юридичних наук за допомогою антрополого-біологізаторського дослідницького підходу, зокрема для пізнання у світлі висновків еволюційної біології, етології, соціології, соціобіології, психології, біологічного напряму фрілософської антропології тощо генезису держави та встановленого (санкціонованого) нею позитивного права. Певні евристичні можливості вказаного методологічного підходу в юриспруденції продемонстровано на прикладі концепції «війни всіх проти всіх» (Т. Гоббс) як природного стану людей у додержавному суспільстві. Розглядаючи задекларовані цим філософом причини виникнення означеної війни (природну рівність людей, страх і бажання влади), автори виявили певні зв'язки між біологічно зумовленою установкою людини на самозбереження, виникненням держави та встановленням нею юридичних норм.

Теорія еволюції допомагає обґрунтувати природну схильність людського індивіда до агресування, а відтак, - частково верифікувати гіпотезу про постійну «війну» людей між собою. У цій боротьбі вибудовуються соціальні ієрархії, які $€$ умовою встановлення та підтримання суспільного порядку. Через юридичні норми держава фрормує у людини відчуття захисту від загроз, придушуючи у такий спосіб заснований на агресії та страху інстинкт самозбереження, який зумовлює, зокрема, бажання влади та $є$ руйнівним для встановлення і збереження соціальних зв'язків між рівними від природи людьми. Норми, які створює чи санкціонує держава, замінюють природну рівність членів суспільства як одну 3 причин «війни всіх проти всіх» формальною, «узаконеною», політичною рівністю. Остання виконує для людей своєрідну компенсаторну функцію: у стані їх фактичної нерівності заміщує «ушкоджену» послабленням агресивності частину людської природи. Послаблюючи, з одного боку, вплив установки на самозбереження, через позитивне право держави, з іншого боку, так би мовити, виповнює «недостатність» для самозбереження людини ії «першої» (біологічної) природи. Внаслідок такого «виповнення», будучи частинами «другої» людської природи (культури), держава та позитивне право виконують функцію адаптації кожної людини до умов її існування.

Ключові слова: методологія юридичної науки, походження держави та права, інстинкт самозбереження, природна та політична рівність, агресія, страх, бажання влади.

DOI: http://dx.doi.org/10.30970/vla.2020.70.010

Вступні зауваги. Належність юридичних наук до суспільних можна пояснити тим, що вони генерують нові знання про ті соціальні явища, виникнення, існування та розвиток яких можливий завдяки людині та ії діяльності у соціумі. Проте для такого генерування важливим є звернення до висновків інших - неюридичних наук. Саме «через методологічний канал, - як зазначив вітчизняний теоретик права, професор П. Рабінович, - вливаються... у «душу» теорії держави та права

(С) Гудима Д., Литвинюк К., 2020 
(як й інших юридичних наук) ті теоретичні цінності, котрими володіють інші науки» [22, с. 36].

На думку французького філософа М. Фуко (Paul-Michel Foucault), гуманітарні науки виключені з «епістемологічного трьохгранника», «трьохвимірного простору», в якому в одному вимірі знаходяться математичні та фізичні науки, в іншому лінгвістика, біологія й економія, а в останньому - філософська рефлексія. Водночас гуманітарні науки включені у цей же простір, оскільки «знаходять своє місце» у «пробілах» між вказаними трьома вимірами [31, с. 366-367]. Якщо, не вдаючись до дискусії про розмежування соціальних і гуманітарних наук [26, с. 69], яка вочевидь чужа для філософії М. Фуко, сприйняти його твердження про те, що існування гуманітарних наук «можливе тільки завдяки їхньому «сусідству» 3 біологією, економією, філологією (чи лінгвістикою)», проекціями яких є гуманітарні науки, і що останні «взагалі не є науками», оскільки «приймають на себе перенесення моделей, запозичених із наук у власному сенсі слова» [31, с. 385], то варто виснувати, що розвитку юридичних наук (як різновиду гуманітарних згідно 3 класифікацією зазначеного філософа) можуть сприяти здобутки, зокрема й біології. Вона, як відомо, вивчає всі живі організми, одним із яких є людина. Тому дослідження соціальних явищ, тобто тих, які пов'язані з поведінковими актами людського індивіда, зумовлює потребу у використанні знань, що продукує біологія та суміжні з нею науки.

Ситуація, за якої соціальні науки, зокрема юридичні, «оберігаються» нібито від «оприродничування», виглядає дивною. Більше того, як зауважив російський теоретик права М. Тарасов, спеціальних досліджень і широкого обговорення «соціогуманітарної» специфіки (іншої, ніж відмова від числових вимірювань і математичного інструментарію природничих наук) не було [26, с. 71]. Повна відмова, умовно кажучи, поширити біологічні закони на інтерпретацію особливостей суспільства та поведінки людини у ньому навряд чи сприяє генеруванню нових знань у соціальних науках. Американський психолог-еволюціоніст С. Канадзава (Satoshi Kanazawa) навіть стверджує, що останні - «це галузі біології, і всі гіпотези у галузі суспільних наук щодо поведінки людини треба узгоджувати зі встановленими принципами та законами біології» [36]. Причину такого бачення пояснює тим, що внаслідок розмежування соціальних наук, які вивчають поведінку людини, й інших наук, які вивчають поведінку всіх живих видів, перші тепер перебувають там, де другі були ще у XVII столітті [37].

Подолати такий розрив, певною мірою зблизити соціальні науки 3 природничими, можна, застосовуючи, зокрема, висновки щодо біологічної природи людини для пізнання соціальних явищ, у тому числі держави та права.

Постановка проблеми та стан ії дослідження. Деякі інтерпретації соціальних явищ у світлі біологічної природи людини можна знайти у представників філософської антропології (А. Гелен (Arnold Gehlen), Г. Плеснер (Helmuth Plessner), А. Портман (Adolf Portmann), М. Шелер (Max Scheler)), органічного напряму у соціології (Р. Вормс (René Worms), В. Г. Самнер (William Graham Sumner), Г. Спенсер (Herbert Spencer), П. Ліліенфельд-Тоаль (Paul Frommhold Ignatius von Lilienfeld-Toal), А. Стронін, А. Ж. Е. Фульє (Alfred Jules Émile Fouillée), А. Е. Ф. Шеффле (Albert Eberhard Friedrich Schäffle)), соціобіології (Е. О. Вілсон (Edward Osborne Wilson), Д. Дж. Moppic (Desmond John Morris), P. Tpiвepc (Robert Trivers)), біології й етології (Дж. К. Вільямс (George Christopher Williams), Дж. Б. С. Голдейн (John Burdon Sanderson Haldane), К. Р. Докінз (Clinton Richard Dawkins) В. Дольник, Л. Л. Каваллі-Сфорца (Luigi Luca Cavalli-Sforza), 
К. 3. Лоренц (Konrad Zacharias Lorenz), Р. М. Сапольський (Robert Morris Sapolsky), Дж. М. Сміт (John Maynard Smith), М. В. Фельдман (Marcus William Feldman)). Однак у сучасній загальнотеоретичній юриспруденції здобутки зазначених наук і наукових напрямів поки не знаходять належного застосування.

Стосовно генези держави та права в юридичній науці є багато гіпотез (див. огляд деяких із них: [13, с. 47-93, 284-299]). Значна частина цих гіпотез заснована на антрополого-соціологізаторському дослідницькому підході, що грунтується на визнанні виключно соціальної зумовленості держави та права. Біологічна природа людини - «творця» та «споживача» означених явищ - невиправдано залишається в Україні поза належною увагою правників, незважаючи на суттєве поглиблення інтересу до проблематики антропології права (В. Бігун, Д. Бочаров, Ю. Лобода, С. Максимов, О. Павлишин, П. Рабінович, Н. Сатохіна, С. Шевцов).

Урахування такої природи у дослідженнях держави та права уможливлює антрополого-біологізаторський методологічний підхід, заснований на визнанні еволюційної природи людини та зумовленості держави і права біологічними властивостями людського індивіда [9, с. 47, 215]. Видається, що так само, як колись учені переконалися в єдності органічного світу та у тому, що, як писав російський натураліст К. Тімірязєв, «всі наші рамки або поділи - тільки витвір нашого розуму, - правда, один із найвеличніших його витворів, без якого він ніколи не справився б з хаосом поодиноких форм» [27, с. 192], так і зараз для об'єктивного пізнання соціальних явищ їхнє відокремлення від явищ біологічних варто сприймати винятково як витвір нашого розуму. Причому такий, який з огляду на досягнутий науково-технічний прогрес почасти гальмує розвиток соціальних наук, іноді невиправдано виокремлюючи суспільні явища 3 органічного світу.

Певний поступ у напрямі зближення чи то, скоріш, відновлення зв'язку наук про суспільство з науками про природу вже зроблений. I, вочевидь, юридичні науки не можуть залишатися осторонь цього процесу. «Об'єднуючи природу й суспільство, вписуючи соціальний фактор у лоно живої організації, утворюючи моделі, які дають змогу вивчати, наприклад, суспільство приматів, соціологія, стверджувала французька філософиня Ж. Рюс (Jacqueline Russ), - здійснює свою справді коперниківську революцію. Звичайно, суспільство мавп ще не виявляє суто людські парадигми..., а проте рів між природою і культурою пощастило засипати» [23, с. 409]. Більше того, «усталений образ тварини як механізму, яким управляє автоматизм інстинкту, - за словами канадського філософа Б. Массумі (Brian Massumi), - демонструє деякі ознаки послаблення, тим самим даючи більший простір індивідуальним варіаціям, що підтверджує злет нової дослідницької сфери етології, присвяченої «особистості» тварини. ... Ми можемо навчитися у тварин можливості побудови того, що Гваттарі [мається на увазі французький психоаналітик, філософ Pierre-Félix Guattari. - Авт.] називає етико-естетичною парадигмою природної політики (natural politics), а не політикою природи (politics of nature). ... Тваринна політика є політикою становлення, навіть - і особливо становлення людини» $[18$, с. $9,51,65]$.

Ще Арістотель, пишучи, що «людина є істота політична більшою мірою, ніж бджоли і всякого роду стадні тварини» [2, с. 17], визнавав, що не тільки людина за іiї природою є політичною істотою, тобто не тільки вона потребує життя у спільноті собі подібних. А сучасні досягнення природничих наук змушують задуматися про значення «політичних властивостей» тварин для розуміння діяльності людини та, так би мовити, створених нею явищ. Російський історик і літературознавець О. Еткінд навіть припускає, що, можливо, у далекому майбутньому всі ресурси 3 
такими властивостями «об'єднає світова держава, якщо вона надасть права громадянства природним явищам і навчиться враховувати їх голоси разом з людськими» $[35$, c. 463$]$.

Проте спершу, мабуть, важливіше подивитися у минуле. Зокрема, аби побачити, що розрив соціальних наук із науками природничими не був і не $\epsilon$ нездоланним. Для прикладу, російський соціолог О. Стронін ще у ХІХ столітті писав, що «вже бджола захищає свої соти та свій вулик, ластівка - своє гніздо та яйця, ведмідь - своє лігво. А тому і в будь-якому зібранні людей, яким би воно не було, невід'ємні, щонайменше, загальнотваринні властивості, а відповідно і прояв права» $[25$, c. 265].

Мета статті. Спробуємо виявити певні евристичні можливості антропологобіологізаторського дослідницького підходу для пізнання держави та позитивного права на прикладі концепції «війни всіх проти всіх» Т. Гоббса (Thomas Hobbes).

Виклад основного матеріалу. «Природна» війна. Ідея боротьби як рушія розвитку суспільства є дуже давньою. Стосовно війни - різновиду такої боротьби, то вона, як зазначив польський теоретик морської війни професор А. Маковський (Andrzej Makowski), «супроводжує людину від витоків іiі історії (старших, ніж держава)» та «є фактичним станом, пов'язаним із регулюванням відносин між державами (іншими суб'єктами конфлікту), опертим на свавілля й насильство, а не на основу права, хоча сама війна не є байдужою до права» $[17$, с. 33,34$]$. Цей стан, на думку американського автора науково-популярної літератури з психології Р. Гріна (Robert Greene), «відомий кожному із нас, проявляє як найкращі, так і найгірші риси нашої натури... війна віддзеркалює умонастрій людського суспільства. Еволюція у бік нешаблонних, скоріш нетрадиційних, але разом 3 тим куди більш брудних стратегій - партизанської війни, тероризму, - відображає аналогічну еволюцію у суспільстві, в якому допустимо та прийнятно майже все» [8, с. 20].

Давньогрецький філософ-досократик Геракліт Ефеський писав, що «війна $\epsilon$ батьком всього, царем всього. Вона зробила одних богами, інших - людьми, одних рабами, інших - вільними... Необхідно знати, що війна загальна, і що правда чвари, і що все зароджується завдяки чварам і $з$ необхідності» $[4$, с. 21,31$]$. Іншими словами, на його думку, стан війни є природним для людського середовища й існує безперервно. Внаслідок війни люди набувають різного статусу та зароджуються всі соціальні явища. Вказане дає підстави виснувати, що належні до цих явищ право та держава теж є наслідками війни. Більше того, оскільки війна розділяє людей, робить їх нерівними, в одержавленому суспільстві нерівність $є$ об'єктивно зумовленою, у цьому сенсі - природною.

Дещо наближений до гераклітового підхід до війни як стану запропонував англійський філософ Т. Гоббс. Він, намагаючись з'ясувати причини й умови виникнення держави та права, припустив, що у природному стані «homo homini lupus est» («людина людині вовк») [6, с. 271]. Його підхід до походження означених явищ засновується на тому, що допоки «люди живуть без загальної влади, яка б усіх тримала у страху, вони перебувають у становищі, яке називається війною, і це війна всіх проти всіх... все, що характерно для воєнного часу, коли кожен стає ворогом кожного, характерно і для того часу, коли люди живуть, не маючи жодних інших гарантій своєї безпеки, крім тієї, яку їм надає їхня власна сила та винахідливість У такому становищі немає місця для працелюбства, бо плоди його непевні: і внаслідок цього немає ні землеробства, ні мореплавства, ні торгівлі заморськими товарами, ні зручних будівель, ні засобів руху та переміщення речей, що вимагають великої сили, ні знання земної поверхні, ні 
врахування часу, ні мистецтв, ні письма, ні суспільства, а найгірше понад усе це постійний страх і небезпека насильницької смерті, і життя людини - самотнє, бідне, безпросвітне, тупе й коротке» [5, с. 153].

Тобто, на відміну від ідеї Геракліта про необмежену у часі загальну війну, Т. Гоббс сформулював ідею війни як природного стану людей у додержавному суспільстві. Цей стан нібито припиняється зі створенням держави. Проте, якими, на думку філософа, є причини виникнення стану «війни всіх проти всіх»?

Природна рівність людей як причина війни. Ця рівність у фізичних i розумових здібностях зумовлює рівність надій на досягнення цілей. Через неї виникає взаємна недовіра: «...якщо двоє бажають одну й ту саму річ, володіти якою вони вдвох не можуть, вони стають ворогами і на шляху до своєї мети... намагаються знищити або підкорити один одного». А така недовіра зумовлює війну, безпосередніми причинами якої є суперництво, невпевненість і прагнення слави [5, с. 151, 152].

Видається, що означена постійна боротьба людей має, насамперед, біологічне підгрунтя, а ії̈ ідея корелює з деякими постулатами еволюційної теорії походження людського індивіда. Про органічну еволюцію писали ще французький натураліст Ж.-Б. Ламарк (Jean-Baptiste Pierre Antoine de Monet, Chevalier de Lamarck) y «Філософії зоології» (1809) і шотландський геолог та видавець Р. Чемберс (Robert Chambers) у праці «Сліди Творіння» (1844). Проте лише Ч. Р. Дарвін (Charles Robert Darwin) у праці «Походження видів шляхом природного добору або збереження обраних рас у боротьбі за життя» (1859) обгрунтував існування органічної еволюції, що відбувалася в минулому і триває далі. Описуючи механіку ії перебігу, вчений сприйняв теорію Т. Мальтуса (Thomas Malthus) про те, що потенціал розмноження живих істот будь-якого виду істотно перевершує наявні ресурси для їх прожитку. Через обмеженість ресурсів істоти змушені вступати у боротьбу за існування. Найбільш гострою вона $\epsilon$ між тваринами одного виду, оскільки особини, що його утворюють, виявляють значно більше однотипних вимог до умов існування. Саме боротьба, своєрідна «війна всіх проти всіх», породжує природній відбір і виживання «найбільш пристосованих», «найсильніших» [10, с. 32-33].

У книзі «Походження людини та статевий добір» (1871) на підставі даних, що вказують на схожість людини і людиноподібних мавп, автор обгрунтував ідею їхньої спорідненості, а отже, і походження від спільного предка [11, с. 265]. Згідно зі заснованою на цій ідеї натуралістичною концепцією людини остання - істота біологічна, особливий вид тварини, «достатньо пізній результат розвитку Землі, істота, яка відрізняється від форм, котрі їй передують у тваринному світі, лише ступенем складності поєднання енергій і здібностей, котрі самі по собі вже зустрічаються у нижчій порівняно з людською природі» [33, с. 31].

Ч. Р. Дарвін писав, що людина та вищі тварини, особливо примати, мають деякі спільні інстинкти, наприклад, почуття самозбереження, статеву любов, любов матері до новонародженого дитинчати [11, с. 187, 198]. Але 3 огляду на те, що людська істота $є$ «недостатньою» [3, с. 175], наявність таких інстинктів, на жаль, не забезпечує їй самозбереження тією мірою, якою тваринам. Як вказував Ф. Ніцше, «ми, коли йдеться про людину, стверджуємо таке: проти всіх інших істот людина, навіть 3 усім іiі цікавущим змістом, - найбезпорадніший і найхоровитіший звір, що, збочивши з битого шляху інстинктів, заблукав у найзгубніших манівцях» [20, с. 342].

Концепцію про філогенетично запрограмоване агресивне начало людини розвивав К. З. Лоренц. Він запропонував розглядати агресію як природний i невід'ємний інстинкт будь-якої тварини, необхідний для збереження окремої 
особини та виду в цілому [15, с. 114-115]. Цю роль агресія виконує, забезпечуючи установлення ієрархії, захист потомства, території та боротьбу за ресурси. Еволюційна теорія допомагає обгрунтувати природну схильність людського індивіда до агресування, а відтак, - частково верифікувати гіпотезу про постійну «війну» людей між собою.

Т. Гоббс уважав, що «деякі живі істоти, як, наприклад, бджоли чи мурахи, живуть дружньо між собою», і внутрішньовидова конкуренція їм невластива [5, с. 186]. В останньому філософ помилявся. У тваринному світі, як і у світі людському, один зі способів зупинення, так би мовити, «війни всіх проти всіх» це встановлення ієрархії (нерівності), що є вітальною умовою для підтримки порядку у групах тварин. Владні особини закріплюють власні позиції у соціумі, здобутий у боротьбі статус дає їм переваги у доступі до їжі, статевих партнерів і наділяє обов’язками щодо захисту території, вразливих членів групи тощо. Аналогічно встановлення нерівності серед людей як умова припинення «війни всіх проти всіх» має наслідком появу суверена, який через договір із підданими закріплює свій статус і визначає статус для інших [5, с. 127, 188]. Норми, які створює держава, що покликана оберігати людей від повернення до такої війни, дозволяють замінити природну рівність членів суспільства як одну з причин цієї війни формальною, «узаконеною» рівністю. Остання виконує для людей своєрідну компенсаторну функцію: у стані їх фактичної нерівності заміщує «ушкоджену» послабленням установки на самозбереження частину людської природи.

У такий спосіб позитивне право виконує завдання зі забезпечення суспільного порядку. «Сей порядок, - писав український учений i політичний діяч С. Дністрянський ${ }^{1}$ - виходить 3 необхідности суспільних зносин між людьми. Чоловік [людина. - Авт.] потребує помочі й охорони. Сю поміч і охорону вони дають собі взаємно: цілий суспільний зв'язок представляє силу, яку мусить розділити між своїх членів. Зв'язок мусить забезпечити своїм членам те, що їм належиться на засаді: suum cuique tribuere ${ }^{2}-$ але, 3 другого боку, мусить жадати, щоби кожний дав чи зробив від себе те, чого треба, щоб усі мали спільну поміч та спільну охорону» [12, с. 71].

Теза про компенсаторний характер юридичних норм, створених державою, як видається, актуальна не тільки для випадку визнання вродженої рівності людей, але й для випадку визнання їхньої природної нерівності. Так, Ф. Ніцше стверджував, що підпорядкованість є проявом вищого закону природи, поділ людей на «три фізіологічні типи» (тих, у кого могутній дух; тих, у кого міцне тіло і незламна вдача; тих, хто не вирізняється ні духом, ні тілом) є «доконечним для існування суспільства», а «нерівноправність є першою передумовою існування будь-якого права взагалі» [20, с. 404, 405]. Тобто, «право - це привілей», який кожен має відповідно до його місця у суспільній ієрархії [20, с. 404, 405]. Проте, коли цей привілей замінює фактичну нерівність формальною рівністю, він теж «компенсує» для частини населення певні недоліки їхнього «природного» стану, дозволяючи, умовно кажучи, тим, у кого могутній дух, відчувати себе тими, у кого міцне тіло та незламна вдача, а тим, хто не вирізняється ні тілом, ні духом, - відчути себе першими та другими. 3 таким нашим підходом вказаний філософ навряд чи би погодився, оскільки, на його думку, саме у «зазіханнях на “рівноправність"» полягає несправедливість [20, с. 406].

\footnotetext{
1 Текст подаємо зі збереженням мови автора.

2 Дати кожному своє (лат.).
} 
Страх як причина війни. Цю причину Т. Гоббс назвав будь-яким передбаченням майбутнього зла, прагненням бігти (від небезпеки), недовірою, підозрою, обережністю, передбачливістю. Філософ уважав, що «всі великі та міцні людські спільноти беруть початок не у взаємній доброзичливості, а у взаємному страху. Його корені криються як у природній рівності людей, так і у взаємному бажанні заподіяти шкоду один одному» [6, с. 287]. «Скрізь, де люди жили невеликими осередками, вони грабували один одного; це вважалося настільки сумісним із природними законами, що в міру награбованого людині відмірялося й поваги» [5, с. 184].

Засновник соціобілогії Е. О. Вілсон переконаний, що люди культивують ворожість, щоби перемогти джерело загрози та забезпечити собі надійну безпеку. Тому страх перед діями чужинців люди намагаються долати за допомогою агресії. Певним підтвердженням цьому є слова індійців яномамо: «Ми втомилися боротися. Ми більше не хочемо вбивати. Але інші небезпечні, і їм не можна довіряти» [28, c. $179-180]$.

Близький за змістом підхід до ворожості як засобу збереження єдності соціальної групи та ії захисту знаходимо у професора В. Старосольського. У праці «Держава і політичне право» (1923-1925) він писав ${ }^{1}$, що у первісному суспільстві «тісному обєднанню в межах групи відповідає ії замкненість та вороже відношення до всего, що находиться поза групою. Хто не належить до групи, цей не тільки чужий, але разом із цим і ворог. Чужий - це "hostis", a "hostis" - це ворог, що тільки на основі особливих, виїмкових умовин стає терпимим в племени, а навіть одержує право користуватися охороною з боку племени. Установа “гостинности", зрозуміла тільки на тлі ворожнечі, що становить основний та постійний зміст взаємин поміж чужими собі групами. ... Первобутня ворожнеча, це "настрій” супроти чужих засадничо недовірчивий та неприхильний» [24, с. 40].

Однак $\epsilon$ аргументи і проти ідеї подолання страху агресією. Так, Е. Фромм уважав, що будь-яка тварина на загрозу ії існуванню реагує або агресією і нападом, або проявом страху та втечею однаковою мірою. Більше того, з позиції біології втеча навіть надійніше сприяє самозбереженню, ніж бійка. А тому, на думку німецького психолога, історія визначалася не стільки агресивними інстинктами, скільки спробою придушити в людині інстинкт втечі. Саме цій меті слугують більшість соціальних інститутів і весь ідеологічний арсенал [30, с. 93].

3 такого погляду держава та право є не лише засобами подолання агресії, яку люди виявляють, зокрема, для самозбереження, але й засобами нейтралізації «рефлексу втечі» як реакції на будь-яку загрозу життю. Задля підтримання стабільності суспільства, забезпечення його безпеки та розвитку людина не повинна боятися ризикувати не тільки іï здоров'ям, майном, але й життям. Держава через відповідні юридичні норми гарантує, наприклад: право на підприємницьку діяльність, здійснення якого пов'язане 3 ризиками неотримання доходу, втрати вкладеного у розвиток справи майна; право на працю, що можна реалізувати, зокрема, на роботах у шкідливих і важких умовах; обов'язок захищати незалежність і територіальну цілісність держави, виконання якого пов'язане з ризиками для життя та здоров'я; обов'язок сплачувати податки і збори у встановлених державою розмірах, що можуть бути надмірно обтяжливими для конкретного платника.

Бажання влади як причина війни. Це - третій, так би мовити, антецедент «війни всіх проти всіх», який у концепції Т. Гоббса визначає асоціальний природний стан людей і $є$ головним: «Отже, на перше місце, як загальну схильність усього

\footnotetext{
${ }^{1}$ Текст подаємо зі збереженням мови автора.
} 
людського роду, я ставлю вічне й невпинне бажання дедалі більшої й більшої влади, бажання, що його уриває тільки смерть. I причиною тут не завжди буває сподівання людини на ще інтенсивнішу насолоду, ніж уже досягнута, і те, що вона не може задовольнитися помірною владою, а й те, що вона не може забезпечити існування цієї влади та засоби для свого теперішнього добробуту без набування ще більшої влади» [5, с. 133].

3 таким трактуванням рушіїв людської поведінки категорично не погоджувався Е.Фромм, стверджуючи, що бажання влади $\epsilon$ «найзначнішим проявом садизму» [29, с. 162]. На думку цього автора, гоббсівська жага влади «була цілком раціональним наслідком людського прагнення до насолоди й безпеки» [29, с. 149]. Але «картина, змальована Гоббсом», на якій люди прагнуть до влади, щоби забезпечити собі на майбутнє все те, що вони мають сьогодні, «вийшла 3 моди» $[29$, с. 19]. Пояснював це німецький психолог так: «Що успішнішим у поваленні влади колишніх політичних чи релігійних можновладців ставав середній клас, що більше людей успішно приборкували сили природи, й коли мільйони індивідів ставали економічно незалежними, то сильнішою ставала віра в раціональний світ та в саму людину як у виключно раціональну істоту. ... 3 часів Гоббса на прагнення до влади дивилися як на основний мотив людської поведінки; але впродовж наступних століть дедалі більшого значення набували юридичні й моральні чинники, спрямовані на обмеження влади» [29, с. 19, 162].

Таке зростання значення цих чинників, на нашу думку, є не стільки доказом того, що помилявся Т. Гоббс, скільки підтвердженням потужності впливу на свідомість людей соціального нормотворення. Впливу, завдяки якому «природне» у людині могло або посилитися, або до певної межі замінюватися «соціальнонормативним». Саме до певної межі, бо спрямованість соціальних норм на обмеження політичної влади аж ніяк не означає їхню спрямованість на цілковите позбавлення жаги влади адресатів цих норм. Видається, що так само, як за фізичними законами енергія не виникає 3 нічого і не зникає нікуди, а може лише перетворюватись в енергію іншого виду, бажання влади під впливом юридичних, моральних, інших соціальних норм зазнає змін, але не зникає. Послаблення державної влади завжди має наслідком зміцнення іншої влади, зокрема влади приватного капіталу, як і навпаки. Одним із засобів реалізації такого процесу «перетворення бажання влади» $\epsilon$ юридичні норми. Іншими словами, послаблення політичної влади є наслідком дії норм, спрямованих на посилення бажання іншої влади, а послаблення дісю норм останнього може зумовлювати зміцнення влади політичної.

К. Шмітт, досліджуючи філософську спадщину Т. Гоббса, писав, що останній, оголосивши рішучий розрив із традиційним уявленням про природну соціальність людини, часто користувався готовими формулами традиційного трактування природного права, розуміння якого склалося ще починаючи зі стоїків [34, с. 33]. Вони вважали, що першою спонукою живої істоти є самозбереження, бо природа спочатку дорога сама собі $[14$, с. 272]. Слідуючи цим твердженням, можна виснувати, що в основі ідеї Т. Гоббса про природний стан $\epsilon$ біологічно зумовлена установка на самозбереження. Така установка - інстинкт, в основі якого, за словами вітчизняного лікаря, професора М. Амосова, закладені біологічні потреби в їжі та захисті [1, с. 46], - мотивує людину агресувати, щоби виборювати ресурси для існування, агресувати від страху, та, врешті, агресувати для панування над іншими людьми. Тому призначення держави, яке Т. Гоббс бачив у забезпеченні миру та захисті громадян, зводиться фактично до послаблення впливу біологічно зумовленої установки на самозбереження, яка $є$ руйнівною для встановлення та 
збереження соціальних зв'язків між рівними від природи людьми. I це послаблення стає можливим унаслідок передання державі турботи про захист населення. Іншими словами, філософ зробив із суверена-держави екзистенціальну одиницю, підпорядковану означеній турботі [16, с. 279]. Щоправда, здійснення останньої, зупинення «війни всіх проти всіх» можливе тільки на зайнятій Левіафаном території. За ії межами він веде війни з іншими Левіафанами та з Природою, і хіба остання може ці війни зупинити.

Зауважимо, що з певними елементами вчення Т. Гоббса співзвучні ідеї Ф. Ніцше. Останній писав: «... в усі часи агресивна людина, як сильніша, мужніша, більш знатна, володіла і вільнішим поглядом, спокійнішою совістю; навпаки, нічого не коштує вгадати, на чиїй совісті взагалі лежить винахід "нечистої совісті", - це людина ressentiment ${ }^{1}$ ! Зрештою, озирніться ж у самій історії: в якій саме сфері осідало взагалі досі на землі дотримання права, власне потреба в праві? Чи, може, у сфері реактивних людей? Анітрохи: але саме у сфері активних, сильних, спонтанних, агресивних. 3 історичного погляду ... право на землі є якраз боротьбою проти реактивних почуттів, війною $з$ ними з боку активних і агресивних сил, які частково звертали свою міць на те, щоби визначити межу та міру надлишкового реактивного пафосу та примусити його до угоди. Всюди, де практикується справедливість, дотримується справедливість, перед очима постає сильна влада...» [19, с. 453-454].

3 указаним корелює ідея Т. Гоббса про те, що у стані «війни всіх проти всіх» «ніщо не може бути несправедливим. Для понять правильного і неправильного, справедливості і несправедливості тут немає місця. Там, де немає загальної влади, немає закону, а там, де немає закону, немає несправедливості. Сила й підступність $\epsilon$ на війні двома головними чеснотами. Справедливість і несправедливість не $є$ здібностями ні тіла, ні розуму» [5, с. 154]. Філософ теж зазначив, що у природному стані через відсутність взаємної довіри, невпевненість в інших людина змушена «силою та хитрістю утримувати у покорі тих, кого можна, доти, доки не побачить ... іншої влади, достатньо потужної, щоб становити для... [неї] небезпеку» [5, с. 152]. Про значення сили та хитрості для ведення війни й отримання у ній переваги писав і російський воєнний історик М. Голіцин [7, с. 73]. Але чи не зумовили саме ці сила, хитрість або підступність як чинники самозбереження людини (або, іншими словами, прояви бажання влади) укладення «суспільного договору»? Тобто, чи не є «суспільний договір» результатом сили, хитрості або підступності окремих людей, які завдяки такому договору, щонайменше, забезпечили собі самозбереження? А сприяли його «укладенню», з одного боку, «страх смерті, бажання речей, необхідних для зручного життя, і надія отримати їх завдяки своєму працелюбству» [5, с. 155], а 3 іншого, - зокрема, «знаки, які виражають договір» (слова, мовчання, дії, утримання від дій) [5, с. 159].

Відповіді на означені питання, вочевидь, варто шукати за межами юриспруденції - у сфері знань про біологічну природу людини. Певну відповідь пропонує, описуючи шляхи здобуття верховної влади, сам філософ: «Один шлях - це фізична сила, наприклад, коли хтось примушує своїх дітей коритися своїй владі, погрожуючи покарати їх у разі відмови, або розпочинає війну і підпорядковує своїй волі ворогів, даруючи їм по тому життя. Інший шлях - це добровільна домовленість людей підкоритися одній особі чи зібранню людей з надією, що ця особа чи це зібрання зможе захистити їх від усіх інших» [5, с. 188]. Але завдяки чому така домовленість стала можливою? Чи не є означені шляхи пов'язаними? Чи не була

\footnotetext{
${ }^{1}$ Озлобленість, ворожість, злість (фр.).
} 
оферта укласти «суспільний договір» пропозицією, від якої, так би мовити, не могли відмовитися менш сильні, хитрі та підступні, ніж той, хто цю пропозицію зробив? Ці питання привертають увагу, зокрема, до вивчення закономірностей поведінки держави у відповідь на посилення чи послаблення бандитського або злодійського світу, до створення права бандитами, про що писав професор С. Шевцов [32, с. 175, 225-290], і до функціонування так званого права злочинних організацій, «злочинного права», яке виділяв у структурі права російський i польський учений Л. Петражицький [21, с. 78-79]. Проте з огляду на мету статті й обмеження іiї обсягу залишаємо зазначені питання для окремого дослідження.

Висновки. Наведені міркування стосовно концепції «війни всіх проти всіх» Т. Гоббса демонструють, що антрополого-біологізаторський підхід дає змогу розширити методологічний інструментарій юридичної науки, зокрема для осмислення генезису права та держави у світлі здобутків еволюційної біології, етології, соціобіології, психології, біологічного напряму філософської антропології тощо. Застосування цього підходу має сприяти інтеграції юридичних наук як з іншими науками про суспільство, так і з науками про природу, частиною якої є соціум і його члени. А 3 огляду на те, що культура - це так звана друга природа людського індивіда, спосіб його адаптації до умов існування, право та держава як частини культури теж $\epsilon$ такими способами і виконують компенсаторну функцію: заповнюють недостатність для самозбереження людини ії «першої» - біологічної - природи. Іншими словами, саме ця природа закономірно зумовлює виникнення права та держави, які тільки на перший погляд видаються суто соціальними явищами.

\section{Список використаних джерел}

1. Амосов Н. М. Природа человека. Киев : Наукова думка, 1983. 224 с.

2. Арiстотель. Політика / пер. з давньогр. і передм. О. Кислюка. Київ : Основи, 2000. 239 с.

3. Гелен $A$. $O$ систематике антропологии // Проблема человека в западной философии: Переводы / Сост. и послесл. П. С. Гуревича; общ. ред. Ю. Н. Попова. Москва : Прогресс, 1988. C. $152-201$.

4. Гераклитъ Ефесскій. О природъ // Фрагменты / пер. В. Нилендера. Москва : Мусагетъ, 1910. C. 145.

5. Гоббс Т. Левіафан / пер. з англ. Київ : Дух і Літера, 2000. 606 с.

6. Гоббс T. О гражданине // Гоббс Т. Сочинения : в 2 т. Москва : Мысль, 1989. Т. 1 / пер. с лат. и англ.; сост., ред. изд., авт. вступ. ст. и примеч. В. В. Соколов. С. 270-506.

7. Голищын Н. С. Всеобщая военная история. Древний мир. Часть первая. От древнейших времен до Александра Великого (356 г. до Р. Х.). Москва: Академический проект; Фонд «Мир», 2017. 395 с.

8. Грин Р. 33 стратегии войны / пер. с англ. Е. Я. Мигуновой. Москва : РИПОЛ классик, 2016. $896 \mathrm{c}$.

9. Гудима Д. А. Права людини: антрополого-методологічні засади дослідження. Львів: Край, 2009. 292 с.

10. Дарвин Ч. Происхождение видов / пер. с 6 англ. изд. К. А. Тимирязева, М. А. Мензбира, А. П. Павлова, И. А. Петровского. Москва, Ленинград : Гос. изд-во биолог. и мед. литературы, $1937.832 \mathrm{c.}$

11. Дарвин Ч. Происхождение человека и половой отбор // Сочинения. Москва : Изд-во АН СССР, 1953. Т. 5 / Под ред. Е. Н. Павловского. - С. 119-656.

12. Дністрянський С. Загальна наука права і політики. Т. 1. Львів : Вид-во УКУ, 2019. 428 с.

13. Кашанина Т. В. Происхождение государства и права : учеб. пособие. 4-е изд., перераб. и доп. Москва : Проспект, 2015. - 304 с. 
14. Лаэртский Диоген. О жизни, учениях и изречениях знаменитых философов / ред. тома и авт. вступ. ст. А. Ф. Лосев; пер. М. Л. Гаспарова. Москва : Мысль, 1986. 571 с.

15. Лорени К. Так называемое зло. К естественной истории агрессии // Лоренц К. Так называемое зло / под ред. А. В. Гладкого; сост. А. В. Гладкого, А. И. Федорова; послесл. А. И. Федорова. Москва : Культурная революция, 2008. С. 86-308.

16. Магун А. В. Единство и одиночество: курс политической философии Нового времени. Москва : Новое литературное обозрение, 2011. 544 с.

17. Маковський A. Морські війни - методологічні проблеми // 3 історії морських війн (студії й нариси) / за ред. А. Аксамітовського та М. Франца ; пер. з польськ. Київ : НікаЦентр, 2018. $436 \mathrm{c.}$

18. Массуми Б. Чему животные учат нас в политике? / пер. с англ. А. В. Морозова, Д. Я. Хамис. Пермь : Гиле Пресс, 2019. 180 с.

19. Ницчше Ф. К генеалогии морали. Полемическое сочинение / пер. К. А. Свасьяна // Ницше Ф. Сочинения в 2-х т. Москва : Мысль, 1996. Т. 2 / сост., ред. и авт. примеч. К. А. Свасьяна; Пер. с нем. С. 407-524.

20. Ніщще Ф. Жадання влади. Спроба переоцінки всіх цінностей // Ніцше Ф. Так казав Заратустра. Жадання влади. Київ : Основи, Дніпро, 1993. С. 329-414.

21. Петражиикий Л. И. Теория права и государства в связи с теорией нравственности в 2 ч. Часть 1. Москва : Юрайт, 2019. 237 с.

22. Рабинович П. М. Проблемы теории законности развитого социализма. Львов : Изд-во при Львов. гос. ун-те Изд. объединения «Вища школа», 1979. 203 с.

23. Рюс Ж. Поступ сучасних ідей: Панорама новітньої науки / пер. $з$ фр. В. Шовкун. Київ : Основи, 1998. 669 с.

24. Старосольський В Й. Держава і політичне право. Ч. 1. Київ : Логос Україна, 2017. 592 с.

25. Стронинг A. Исторія общественности. С.-Петербургъ: Типографія Министерства путей сообщенія (А. Бенке), $1885.771 \mathrm{c}$.

26. Тарасов М. Юридична наука та наукова раціональність (до питання про філософськометодологічне визначення юриспруденціі) // Філософія права і загальна теорія права. 2012. № 1. С. 68-76.

27. Тімірязєв К. А. Життя рослини. Десять загальноприступних читань / пер. 3 рос. Київ, Харків : Держ. вид-во сільськогосподарської літератури УРСР, 1946. 239 с.

28. Уилсон Э. О. О природе человека / пер. с англ. Т. О. Новиковой. Москва : Кучково поле, 2015. $409 \mathrm{c}$.

29. Фромм Е. Втеча від свободи / пер. з англ. М. Яковлєва. Харків : Книжковий Клуб «Клуб Сімейного Дозвілля», 2019. 288 с.

30. Фромм Э. Анатомия человеческой деструктивности / пер., авт. вступ. ст. П. С. Гуревича. Москва : Республика, 1994. 447 с.

31. Фуко М. Слова и вещи. Археология гуманитарных наук / пер. с фр. В. П. Визгина, Н. С. Автономовой. Москва : Прогресс, 1994. 406 с.

32. Шевцов С. Метаморфозы права. Право и правовая традиция. Москва: ИД Высшей школы экономики, 2014. 408 с.

33. Шелер М. Положение человека в космосе // Проблема человека в западной философии: Переводы / сост. и послесл. П. С. Гуревича; общ. ред. Ю. Н. Попова. Москва : Прогресс, 1988. C. 31-95.

34. Шмитт К. Левиафан в учении о государстве Томаса Гоббса / пер. с нем. Д. В. Кузницына. Санкт-Петербург : Владимир Даль, 2006. 300 с.

35. Эткинд А. Природа зла. Сырье и государство. Москва : Новое литературное обозрение, 2020. $504 \mathrm{c}$. 
36. Kanazawa S. Social sciences are branches of biology. I. Hydrogenology, anyone? URL: https://www.psychologytoday.com/ca/blog/the-scientific-fundamentalist/200909/socialsciences-are-branches-biology-i (viewed on April 30, 2020).

37. Kanazawa S. Social sciences are branches of biology. II. Why all good science is reductionist. URL: https://www.psychologytoday.com/ca/blog/the-scientific-fundamentalist/200909/socialsciences-are-branches-biology-ii (viewed on April 30, 2020).

\section{References}

1. Amosov, N. M. (1983). Priroda cheloveka. Kiev : Naukova dumka.

2. Aristotle (2000). Polityka. Kyiv: Osnovy.

3. Gehlen, A. (1988). O sistematike antropologii. Problema cheloveka v zapadnoj filosofii: Perevody. Moskva : Progress, 152-201.

4. Heraclitus of Ephesus (1910). O prirodb. Fragmenty. Moskva : Musaget, 1-45.

5. Hobbes, T. (2000). Leviafan. Kyiv : Dukh i Litera.

6. Hobbes, T. (1989). O grazhdanine. Sochinenija v 2 t. Moskva : Mysl', T. 1, 270-506.

7. Golicyn, N. S. (2017). Drevnij mir. Ot drevnejshih vremen do Aleksandra Velikogo (356 g. do R. H.). Vseobshhaja voennaja istorija. Moskva : Akademicheskij proekt; Fond «Mir», T. 1.

8. Grin, R. (2016). 33 strategii vojny. Moskva : RIPOL klassik.

9. Hudyma, D. (2009). Prava liudyny: antropoloho-metodolohichni zasady doslidzhennia. Lviv : Kraj.

10. Darwin, Ch. (1937). Proishozhdenie vidov. Moskva, Leningrad: Gos. izd-vo biolog. i med. literatury.

11. Darwin, Ch. (1953). Proishozhdenie cheloveka i polovoj otbor. Sochinenija. Moskva : Izdatel'stvo AN SSSR, T. 5, 119-656

12. Dnistrians'kyj, S. (2019). Zahal'na nauka prava i polityky. Lviv : Vyd-vo UCU, T. 1.

13. Kashanina, T. V. (2015). Proishozhdenie gosudarstva i prava: Uch. pos. Moskva : Prospekt.

14. Laërtius, Diogenes (1986). O zhizni, uchenijah i izrechenijah znamenityh filosofov. Moskva : Mysl'.

15. Lorenz, K. (2008) Tak nazyvaemoe zlo. K estestvennoj istorii agressii. Tak nazyvaemoe zlo. Moskva : Kul'turnaja revoljucija, 86-308

16. Magun, A. V. (2011). Edinstvo i odinochestvo: Kurs politicheskoj filosofii Novogo vremeni. Moskva : Novoe literaturnoe obozrenie.

17. Makovs'kyj, A. (2018). Mors'ki vijny - metodolohichni problemy. Z istorii mors'kykh vijn (studii j narysy). Kyiv : Nika-Tsentr.

18. Massumi, B. (2019). Chemu zhivotnye uchat nas v politike? Perm' : Gile Press.

19. Nietzsche, F. (1993). Zhadannia vlady. Sproba pereotsinky vsikh tsinnostej. Tak kazav Zaratustra; Zhadannia vlady. Kyiv : Osnovy, Dnipro, 329-414.

20. Nietzsche, F. (1996). K genealogii morali. Polemicheskoe sochinenie. Sochinenija $v 2 t$. Moskva : Mysl', T. 2, 407-524.

21. Petrazhickij, L. I. (2020). Teorija prava i gosudarstva $v$ svjazi s teoriej nravstvennosti $v 2 \mathrm{ch}$. Moskva : Jurajt, Ch. 1.

22. Rabinovych, P. M. (1979). Problemy teorii zakonnosti razvitogo socializma. Lvov: Izd-vo pri Lvov. gos. un-te Izd. objedinenija "Vyshcha shkola".

23. Russ, J. (1998). Postup suchasnykh idej: Panorama novitn'oi nauky. Kyiv : Osnovy.

24. Starosol's'kyj, V. J. (2017). Derzhava i politychne pravo. Kyiv : Lohos Ukraina, Ch. 1.

25. Stronin, A. (1885). Istorija obshhestvennosti. S.-Peterburg: Tipografija Ministerstva putej soobshhenija (A. Benke).

26. Tarasov, M. (2012). Yurydychna nauka ta naukova ratsional'nist' (do pytannia pro filosofs'kometodolohichne vyznachennia iurysprudentsii). Filosofiia prava i zahal'na teoriia prava, № 1 .

27. Timiriaziev, K. A. (1946). Zhyttia roslyny. Desiat' zahal'noprystupnykh chytan'. Kyiv, Kharkiv : Derzh. vyd-vo sil's'kohospodars'koi literatury URSR.

28. Wilson, E. O. (2015). O prirode cheloveka. Moskva : Kuchkovo pole. 
29. Fromm, E. (2019). Vtecha vid svobody. Kharkiv : Knyzhkovyj Klub "Klub Simejnoho Dozvillia".

30. Fromm, E. (1994). Anatomija chelovecheskoj destruktivnosti. Moskva: Respublika.

31. Foucault, M. (1994). Slova i veshhi. Arheologija gumanitarnyh nauk. Moskva : Progress.

32. Shevcov, S. (2014). Metamorfozy prava. Pravo i pravovaja tradicija. Moskva: ID Vysshej shkoly ekonomiki.

33. Scheler, M. (1988). Polozhenie cheloveka v kosmose. V Problema cheloveka $v$ zapadnoj filosofii : Perevody. Moskva : Progress, 31-95.

34. Schmitt, C. (2006). Leviafan v uchenii o gosudarstve Tomasa Gobbsa. S.-Peterburg : Vladimir Dal'.

35. Jetkind, A. (2020). Priroda zla. Syr'e i gosudarstvo. Moskva : Novoe literaturnoe obozrenie.

36. Kanazawa, S. (2009, September 21) Social sciences are branches of biology. I. Hydrogenology, anyone? Retrieved from https://www.psychologytoday.com/ca/blog/the-scientific-fundamentalist/200909/social-sciences-are-branches-biology-i.

37. Kanazawa, S. (2009, September 27) Social sciences are branches of biology. II. Why all good science is reductionist. Retrieved from https://www.psychologytoday.com/ca/blog/thescientific-fundamentalist/200909/social-sciences-are-branches-biology-ii

\title{
CERTAIN HEURISTIC POSSIBILITIES OF THE BIOLOGY-DRIVEN ANTHROPOLOGICAL APPROACH IN THE GENERAL THEORY AND PHILOSOPHY OF STATE AND LAW
}

\author{
D. Hudyma, K. Lytvyniuk \\ Ivan Franko National University of Lviv, \\ 1, Universytetska Str., Lviv, Ukraine, 79000, \\ e-mail:dmytro.hudyma@gmail.com,lutvunykk@gmail.com
}

The idea of the possibilities of expanding the methodological tools of legal sciences with the application of a biology-driven anthropological approach, in particular, to cognize the genesis of the state and a created (sanctioned) positive law using the conclusions of evolutionary biology, ethology, sociology, sociobiology, psychology, the biological direction in philosophical anthropology, etc., is presented in the article. Certain heuristic possibilities of this methodological approach in jurisprudence are shown by the example of the concept of "the war of all against all" (T. Hobbes) as the natural state of people in the pre-state society. Examining the reasons declared by this philosopher for the emergence of such a war (natural equality of people, fear, and desire for power), the authors identify certain links between the biologically determined attitude of humans to self-preservation, the emergence of the state and establishing legal norms.

The evolutionary theory of human origins helps to substantiate the natural tendency of man to aggression, and thus - to verify the hypothesis of a constant "war" between people. Social hierarchies, acting as a condition for establishing and maintaining public order, are built in this struggle. The construction of such hierarchies (inequalities) is one of the functions of aggression and results in the formation of the state as an organization secured by political power. Norms created or sanctioned by the state replace the natural equality of members of society as one of the causes of "the war of all against all" with formal, "legalized", political equality. The latter performs a kind of the compensatory function for people: in a state of their actual inequality, it replaces the part of human nature "damaged" by the weakening of aggression.

Fear, like aggression, is a response to a threat to life, but in biology terms fear provides a more reliable self-preservation. Social institutions, in particular, the state and positive law, contribute to overcoming human aggression and fear of external threats. Designed to stop (in 
fact, weaken) "the war of all against all", the state takes measures to ensure peace and protect people in order to weaken the natural desire of some to dominate others. By legal norms, the state forms a person's sense of protection from the threats, thus suppressing the instinct of self-preservation which is based on aggression and fear, determines, in particular, the desire for power and is destructive for establishing and maintaining social ties between naturally equal people.

On the one hand, the state weakens the influence of the human installation on selfpreservation by using positive law, but on the other hand, if you will, it fills the "insufficiency" of the "first" (biological) human nature for this self-preservation. As a result of such "filling", being part of the "second" human nature (culture), the state and positive law perform the function of adaptation of each person to the conditions of his/her existence.

Keywords: methodology of legal science, origins of state and law, instinct of selfpreservation, natural and political equality, aggression, fear, desire for power.

Стаття: надійшла до редакції 10.06.2020 прийнята до друку 12.06.2020 